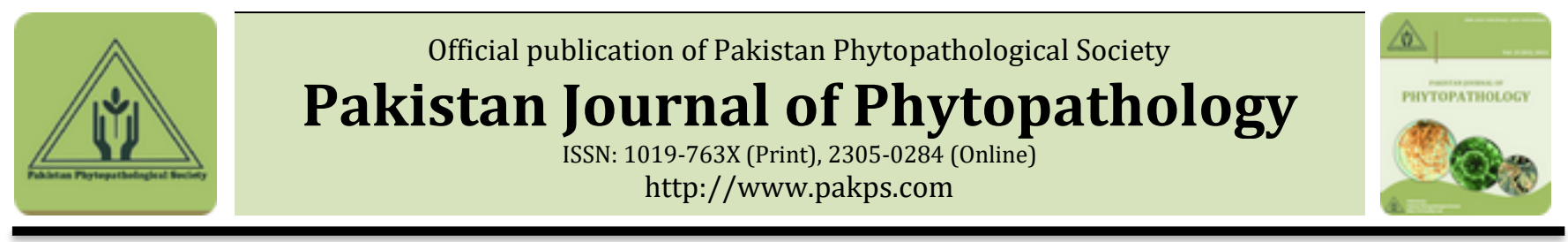

\title{
GENOTYPIC AND BIOCHEMICAL VARIATION IN THE RESPONSE OF BARLEY TO THE ROOT-KNOT NEMATODE (MELOIDOGYNE JAVANICA) AT SEEDLING STAGE
}

\author{
aMajid S. Bajestani, aEsmat M. Moghadam*, bReza Aghnoum, aHamid Rohani \\ a Department of plant protection (Nematology) at Ferdowsi University of Mashhad, Iran. \\ ${ }^{b}$ Seed and Plant Improvement Research Department, Khorasan Razavi Agricultural and Natural Resources Research and \\ Education Center, AREEO, Mashhad, Iran.
}

\section{A B S T R A C T}

The present study was conducted to evaluate 28 commercial cultivars and two promising breeding lines of barley in terms of resistance to Meloidogyne javanica nematode and to investigate the synthesis level of peroxidase, superoxide dismutase, catalase and polyphenol oxidase enzymes in different days after inoculation in greenhouse condition. Based on the results of evaluation, Jolge and Nimrouz cultivars were highly resistant, Rihan and Zarjow were very susceptible. The rest of the cultivars were ranked between these groups in resistant, moderately resistant and moderately susceptible groups. Comparison of the activity of antioxidant enzymes in highly resistance cultivars (Jolge and Nimrouz) and very susceptible cultivars (Rihan and Zarjow) roots showed that the activity of peroxidase, superoxide dismutase and polyphenol oxidase increased in the root of the highly resistant cultivars and decreased or remains unchanged in very susceptible cultivars. Nevertheless, catalase showed a decreasing trend after inoculation by nematodes in highly resistance cultivars, and in general; its level in resistant cultivars was less than susceptible cultivars. Therefore, changes in the activity of these enzymes can be attributed to different levels of resistance among these cultivars.

Keywords: Barley cultivars, Enzymes, Meloidogyne javanica, Resistance, Susceptible.

\section{INTRODUCTION}

Barley (Hordeum vulgare L.) is one of the most important agricultural crops and ranked as fourth most important cereal crops after wheat, corn and rice in terms of global production (Czembor et al., 2007). Internal parasitic nematodes are very important plant parasitic nematodes in agriculture that impose a lot of damage annually to agricultural crops in different regions of the world (Abad et al., 2003). The most important plant parasitic nematodes belong to the genus Meloidogyne (Moens et al., 2009). This group of nematodes secrete substances that cause hypertrophy and hyperplasia conditions in the root parenchyma after entering the host roots. $M$. javanica is considered the most important species in the Submitted: October 26, 2018

Revised: January 30, 2019

Accepted for Publication: February 13, 2019

* Corresponding Author:

Email: mahdikhani_e@yahoo.com

(C) 2017 Pak. J. Phytopathol. All rights reserved.
Meloidogyne genus (Dhandaydham et al., 2008; Caillaud et al., 2008). One of the best management stratagies in an integrated pest management program is using nematode resistant cultivars (Suzuki et al., 2012). In some reports, barley is introduced as a resistant crop to the RKNs that can be sown in contaminated lands to reduce the population of RKNs (Karajeh et al., 2011; Harris and Maramorosch, 2013). Various interactions have been studied between the host plants and RKNs. EL-Mesalamy (2013) examined resistance of some field crops such as wheat, barley and broad bean to RKN, $M$. javanica. They demonstrated a significant reduction in root and shoot fresh weight in all tested plants and slight resistance was mentioned for barley cultivars. In another study, the resistance of barley and wheat cultivars to RKNs, Meloidogyne spp. were examined and it was concluded that all barley cultivars were resistant to $M$. arenaria but susceptible or moderately susceptible to M. javanica (Ibrahim et al., 1988). The resistance of some plant cultivars to RKNs has been the 
subject of several studies (Opperman et al., 1988; Kaloshian et al., 1989; Hussain et al., 2016; Kayani and Mukhtar, 2018).

Nematode damages, as well as other stressors can also stimulate the production of free intracellular radicals of oxygen, including superoxide $\left(\mathrm{O}_{2}^{-}\right)$, hydrogen peroxide $\left(\mathrm{H}_{2} \mathrm{O}_{2}\right)$ and hydroxyl (Sairam and Tyagi, 2004). These compounds incur a lot of damages via oxidation of lipids, proteins, and nucleic acids into cells (Blokhina et al., 2003). Several proteins are produced in the resistant host after the invasion of pathogens that interfere in resistance mechanisms (Mehta et al., 2008). PROX, PPO, CAT, and SOD have a very important role in response to various stressors that would collect produced oxygen free radicals at stress time and by various oxidations take part in defense mechanisms of the plant (Mittler, 2002). In other words, plants infection by a pathogen alters the activity of oxidizing and hydrolyzing enzymes (Mohammadi and Kazemi, 2002). Several reports exist regarding the association between increased activities of oxidizing enzymes, especially PROX (Rani et al., 2008; Arun et al., 2010; Mahdy and Sally, 2011; Anjum et al., 2012). Usually, the activities of these enzymes in the infected resistant tissues are more than infected tissues of susceptible cultivars (Sankar et al., 2017). The main objective of the current research was to find the sources of RKN resistance among commercial cultivars and promising breeding lines of barley. Furthermore, to determine the relationship between the levels of resistance with the antioxidant enzymes synthesis. Such studies have been conducted on other plants including tomatoes (Singh and Khurma, 2007), cucumbers (Aboulipour et al., 2011), cowpea (Oliveira et al., 2012), Okra (Mukhtar et al., 2014) and Sweet Potato (Karuri et al., 2017), but so far, no comprehensive study has been conducted on barley varieties for resistance to root-knot nematodes in Iran. The main objective of this study was to investigate resistance levels of 28 commercial cultivars and two promising breeding lines of barley to Meloidogyne javanica through the study of growth and pathogenicity factors. In addition, after identifying susceptible and resistant varieties, the activity of enzymes related to resistance was investigated, to determine which of these enzymes and to what extent they have contributed to the of resistance phenotype.

\section{MATERIALS AND METHODS}

Plant materials: In this experiment, 28 commercial cultivars and 2 promising breeding lines of barley were used to evaluate their reaction to $M$. javanica (that is improved by morphometric and molecular methods). Details of these cultivars and lines are presented in (Table 1).

Nematodes population: In order to prepare the initial population of the nematode ( $M$. javanica), sampling was done from infected samples in greenhouses in the Kashmar city from Khorasan Razavi province, northern East Iran. Samples were placed in special plastic bags, then along with ice, they were transferred to the laboratory and stored at $4^{\circ} \mathrm{C}$.

Morphological and Molecular identification: Nematodes were first extracted from soil samples by using the Jenkins (1964) method and fixed by using the method of De Grisse (1969). Permanent slides were taken to evaluate the morphological and morphometric characteristics of the samples. The samples were identified using the Taylor and Netscher (1974) modified method. The slices of the cuticular network of the adult female body were prepared based on the method suggested by Hartman and Sasser (1985), and the second instar larvae were identified using Jepson (1987) method. The morphometric characterization of nematodes was conducted by using the Olympus CX41 microscope equipped with a drawing tube, also necessary morphological characteristics factors to identify the species were measured. Then species were identified by valid keys.

To confirm the accuracy of identified species, molecular analysis was performed based on the Ghaderi et al. (2014) method. A single live nematode from pure culture (population of $M$. javanica was reared with single egg-mass inoculation on young tomato seedling for pure culture) was selected and transferred to a small drop of AE buffer (10 mM Tris$\mathrm{Cl}, 0.5$ mM EDTA; $\mathrm{pH}$ 9.0) on a clean slide and crushed by using a clean slide cover. The suspension was collected from the slide by adding $20 \mu \mathrm{l} \mathrm{AE}$ buffer. DNA samples were kept at $-20^{\circ} \mathrm{C}$ until being used as PCR templates. The optimal thermo-cycling conditions include three phases as follows: initial denaturation at $95{ }^{\circ} \mathrm{C}$ for $4 \mathrm{~min} ; 35$ amplification cycles $\left(94^{\circ} \mathrm{C}\right.$ for 30 $\mathrm{s} ; 52{ }^{\circ} \mathrm{C}$ for $40 \mathrm{~s} ; 72{ }^{\circ} \mathrm{C}$ for $80 \mathrm{~s}$ ); and final extension at $72{ }^{\circ} \mathrm{C}$ for $10 \mathrm{~min}$. PCR products were cleaned and send for sequencing (Table 2). 
Table 1. Barley Cultivars and lines used in this study.

\begin{tabular}{|c|c|c|c|c|}
\hline No. & Cultivar/line & Pedigree & Growth habit & Year of release \\
\hline 1 & Makouee & Star & Winter & 1990 \\
\hline 2 & Bahman & WA 2196-68/NY6005-18, F1//Scotia I & Winter & 2008 \\
\hline 3 & Yousouf & $\begin{array}{l}\text { Lignee 527/Chn-01//Gustoe/4/Rhn-08/3/Deir Alla } \\
\text { 106//Dl71/Strain 205 }\end{array}$ & Spring & 2009 \\
\hline 4 & Nosrart & Karoon/Kavir & Facultative & 2008 \\
\hline 5 & Nik & Lignee 527/NK1272//JLB 70-63 & Spring & 2011 \\
\hline 6 & Behrokh & Novosadski-444 & Spring & 2013 \\
\hline 7 & Fajre-30 & Lignee131/ Gerbel//Alger-Ceres & Facultative & 2008 \\
\hline 8 & Rihan & Rihane & Spring & 1994 \\
\hline 9 & Nimrouz & Trompillo & Spring & 2008 \\
\hline 10 & Sahra & LB.Iran/Una8271//Gloria"S"/Com"S" & Spring & 2003 \\
\hline 11 & Jonoub & Gloria "S "/Copal "S " & Spring & 1997 \\
\hline 12 & Zahak & Poa/Hjo/Ojina & Spring & 2012 \\
\hline 13 & Walfajre & CI-108985 & Facultative & 1985 \\
\hline 14 & Kavir & Arivat & Facultative & 1979 \\
\hline 15 & Zarjow & Landrace (Hamedan) & Facultative & 1949 \\
\hline 16 & Aras & Arumir & Spring & 1988 \\
\hline 17 & Loot & Congona/Borr & Spring & 2012 \\
\hline 18 & Rihan-03 & Rihan-03 & Spring & - \\
\hline 19 & Karoon & Strain 205 & Spring & 1980 \\
\hline 20 & Dasht & Probestdwarf & Facultative & 1993 \\
\hline 21 & Torkman & Rihane "S "-04 & Spring & 1993 \\
\hline 22 & Torsh & Landrace (Khorasan) & Spring & - \\
\hline 23 & Afzal & Chah Afzal (Landrace Yazd) & Facultative & 1996 \\
\hline 24 & Govharan & Rhn-03//L.527/NK1272 & Spring & 2016 \\
\hline 25 & Khatam & LB.Iran/Una 8271//Gloria"s"/Com"s"/3/Kavir & Facultative & 2016 \\
\hline 26 & Mehr & Roho/Mazorka//Trompi & Facultative & - \\
\hline 27 & CB-91-8 & Makouee/C.C89//Rihane"s"/3/Roho/Mazurka & Winter & - \\
\hline 28 & CB-91-10 & Torsh/Lgia & Winter & - \\
\hline 29 & Jolge & Makouee//Zarjow/80-5151 & Winter & 2015 \\
\hline 30 & Mahtab & Berake-54 & Winter & - \\
\hline
\end{tabular}

Table 2. Sequence of 18 s primer.

\begin{tabular}{llll}
\hline Primer name & 5'-3' $^{\prime}$ & Gene region & Reference \\
\hline 1813F (forward) & CTGCGTGAGAGGTGAAAT & $18 \mathrm{~s}$ & Holterman et al., 2008 \\
2646R (reverse) & GCTACCTTGTTACGACTTTT & $18 \mathrm{~s}$ & Holterman et al., 2008 \\
\hline
\end{tabular}

Mass propagation of nematode: Susceptible tomato cultivar (Mobil) was planted in sterilized (autoclaved for one hour at $121^{\circ} \mathrm{C}$ and 2.1 atmospheric pressure) medium of farm soil, peat and sand (1:1:1) for proliferation of RKNs. Mass and purified cultivation were obtained according to Fassuliotis (1979) method. In order to extract inoculum, Hussey and Barker (1973) method was used. Holes were made near the root of each plant and $2000 \pm 10$ juveniles were inoculated when the barleys were in 3-4 leaf period. Plants were placed at a temperature of 25 to $30^{\circ} \mathrm{C}$ in the greenhouse.

\section{INOCULATION EXPERIMENTS AND STATISTICAL ANALYSES}

The experiment was performed in a completely randomized design with three replications for each barley genotypes. The same conditions were also used for control treatments. For the measurement of parameters, 60 days after inoculation, plants with minimal damage to their roots were taken out of the pot and after washing the roots, growth factors like root and shoot length and their fresh/dry weight (Kayani et al., 2018; Mukhtar, 2018) were measured. 
Nematode induced factors such as the number of larvae per 100 grams of soil around the roots, egg number per gram root, and the number of galls and bags in per gram root (Whitehead and Hamming, 1965; De Grisse, 1969; Taylor and Sasser, 1978) were performed. The final population of nematodes in the soil was obtained by De Grisse (1969) method. Whitehead and Hamming (1965) method was used in centrifugal flotation and the nematode reproduction factor was conducted by dividing the final population to the initial population. Indexing ratings to the gall per gram of roots was according to Taylor and Sasser method (1978).

Determination of antioxidants enzymes: Total protein was extracted based on the method described by Kar and Mishra (1976). To achieve this, root tissues were sampled every day and directly used for the extraction of protein. For each sample, $200 \mathrm{mg}$ of tissue was ground in liquid nitrogen using a mortar and pestle. Then $3 \mathrm{ml}$ of $100 \mathrm{mM}$ sodium phosphate buffer (pH 6.8) was added and properly mixed. Then the samples were centrifuged at $17000 \times \mathrm{g}$ for $15 \mathrm{~min}$ at $4^{\circ} \mathrm{C}$. The supernatant (enzyme extract) was transferred to new microtube on ice until assayed. Protein concentration was measured using Bradford method, in which bovine serum albumin (BSA) was used as a standard protein (Bradford, 1976).

Superoxide Dismutase (SOD): Total SOD activity was measured using the method described by $\mathrm{Yu}$ and Rengel (1999). Illumination of riboflavin in the presence of $\mathrm{O}_{2}$ and electron donor (like methionine) produces superoxide anion $\left(\mathrm{O}^{2-}\right)$. The $\mathrm{O}^{2-}$ reacts with NBT and reduction of NBT with $\mathrm{O}^{2-}$ produces a blue coloured formazan that can be measured at the wavelength of $560 \mathrm{~nm}$. The principle of SOD activity assay was based on the inhibition of NBT photochemical reduction. Percentage of inhibition was calculated using the formula described by Abrahim et al., (2012). In SOD activity assay, the reaction mixture consisted of $100 \mu \mathrm{l}$ EDTA $(1 \mathrm{mM}), 100 \mu \mathrm{l}$ HEPES (500 $\mathrm{mM}), 100 \mu \mathrm{l} \mathrm{Na}_{2} \mathrm{CO}_{3}(500 \mathrm{mM}, \mathrm{pH}$ 10.4), $100 \mu \mathrm{l}$ methionine $(130 \mathrm{mM}), 100 \mu \mathrm{l}$ Triton $\mathrm{X}-100 \quad(0.25 \%$ $\mathrm{w} / \mathrm{v}), 10 \mu \mathrm{l}$ NBT $(7.5 \mathrm{mM}), 50 \mu \mathrm{l}$ enzyme extract in 430 $\mu$ sodium phosphate buffer ( $100 \mathrm{mM}, \mathrm{pH} 6.8)$ and $10 \mu \mathrm{l}$ riboflavin $(200 \mu \mathrm{M})$ as starter of reaction. After incubation under fluorescent light for $10 \mathrm{~min}$, A560 was measured for each sample. One SOD unit is known as the amount of enzyme that inhibited the rate of NBT reduction by $50 \%$. The SOD activity was expressed as $\mathrm{U}$ SOD mg-1 protein (Beauchamp and Fridovich, 1971).

Peroxidase (PROX): PROX activity was measured using guaiacol as electron donor substrate. The reaction contained $955 \mu$ l potassium phosphate buffer ( $50 \mathrm{mM}, \mathrm{pH}=6.8$ ), $15 \mu \mathrm{l}$ guaiacol $\left(900 \mathrm{mM}\right.$ ), $20 \mu \mathrm{l} \mathrm{H}_{2} \mathrm{O}_{2}$ $(400 \mathrm{mM})$ and $10 \mu \mathrm{l}$ enzyme extract. The reaction was initiated by adding $\mathrm{H}_{2} \mathrm{O}_{2}$ and guaiacol oxidation was measured at $470 \mathrm{~nm}$ using spectrophotometer. Enzyme activity, expressed as $\mu \mathrm{mol} \mathrm{min}^{-1} \mathrm{mg}^{-1}$ protein of oxidized guaiacol, was calculated using the extinction coefficient of $26.6 \mathrm{mM}^{-1} \mathrm{~cm}^{-1}$ for guaiacol (Lin and Kao, 1999).

Catalase (CAT): In order to measure CAT activity, the method described by Aebi (1984) was used. The reaction mixture contained $20 \mu \mathrm{l}$ enzyme extracts, 960 $\mu \mathrm{l}$ phosphate buffer $(50 \mathrm{mM}, \mathrm{pH} 6.8)$ and $20 \mu \mathrm{l} \mathrm{H}_{2} \mathrm{O}_{2}$ $(100 \mathrm{mM})$. It was recorded spectrophotometrically at $240 \mathrm{~nm}$, expressed as $\mu \mathrm{mol} \mathrm{min}{ }^{-1} \mathrm{mg}^{-1}$ protein and calculated by means of the extinction coefficient of 36 $\mathrm{mM}^{-1} \mathrm{~cm}^{-1}$ for $\mathrm{H}_{2} \mathrm{O}_{2}$.

Polyphenol Oxidase (PPO): For PPO assay, catechol solution $(0.3 \mathrm{ml})$ and phosphate buffer $(2.5 \mathrm{ml})$ were placed in a cuvette and measured using spectrophotometer at $495 \mathrm{~nm}$. The enzyme extracts $(200 \mu \mathrm{l})$ were added to the solution obtained from the last phase and the change in absorbance was recorded for every $30 \mathrm{~s}$ up to $5 \mathrm{~min}$. One unit of catechol oxidase or lactase is defined as the amount of enzyme that transforms one $\mu$ mole of dihydrophenol to one $\mu$ mole of quinine/minute (Esterbauer et al., 1977).

Data were analyzed by ANOVA and mean comparisons were made using LSD test at probability level of $\mathrm{P}<0.05$ using SPSS software version 23.

Hierarchical cluster analysis of resistance of 28 commercial barley cultivars and two promising breeding lines against root-knot nematode were made with SPSS based on their field performances.

\section{RESULTS}

Barley cultivars demonstrated different responses $(P<0.05)$ to $M$. javanica (Table 3). The population of $M$. javanica multiplied on all the cultivars as indicated by the number of galls, reproduction factors, change in plant length and fresh/dry weight compared to control (Table 4). Presence of galls and egg-masses on the root of all barley cultivars showed that none of them was immune to RKN infection. The root galls among thirty cultivars were variable in number and size. 
Table 3. Analysis variance of nematodes induced and growth parameters.

\begin{tabular}{|c|c|c|c|c|c|c|}
\hline $\begin{array}{l}\text { Sources } \\
\text { changes }\end{array}$ & $\mathrm{DF}$ & \multicolumn{4}{|c|}{ Mean squares } & $\begin{array}{c}\text { Change plant } \\
\text { length }(\%)\end{array}$ \\
\hline Cultivar & 29 & $1197.11^{* *}$ & $\begin{array}{c}4.92 \\
* *\end{array}$ & $680.74^{* *}$ & 1140.63 ** & 79.72 ** \\
\hline Error & 60 & 103.65 & 1.12 & 0.607 & 1.75 & 4.27 \\
\hline
\end{tabular}

**significant at $\mathrm{P}<0.01$.

Assessment of root galls, RF and growth factors: Cluster analysis was based on nematode induced and growth factors (Table 4) and cultivars were divided into 6 categories by SPSS software (Figure 1). Rihan cultivar was ranked in a very susceptible category because it demonstrated the highest susceptibility compared to other 29 cultivars, with the highest number of gall (103.48) as well as the highest amount of reproduction factors (7.45). Moreover, fresh/dry weight and plant height in this cultivar showed the highest percentage of change compared to control $(70.51,80.31$, and $28.31 \%$, respectively) (Table 4). Zarjow was placed in the second category in terms of susceptibility to M. javanica than the rest of the cultivars. On the contrary, Jolge and Nimrouz cultivars, showed the highest resistance to M. javanica and the disease could not affect them a lot. Jolge had the lowest number of gall (19.06) and reproduction factors (1.53) when compared with other cultivars, and its fresh/dry weight and height were not significantly different from its control (2.12, 4.76 and 2.14\%, respectively) (Table 4). Jolge and Nimrouz can be described as the most resistant cultivars that are classified in the highly resistant category. A large number of cultivars showed median behaviour, such that they are ranked as resistant and moderately resistant categories including 18 cultivars. Slightly susceptible category including six cultivars and disease had a negative effect on their growth compared to the previous category. These cultivars had a higher number of gall and reproduction factor of nematode (Figure 1).

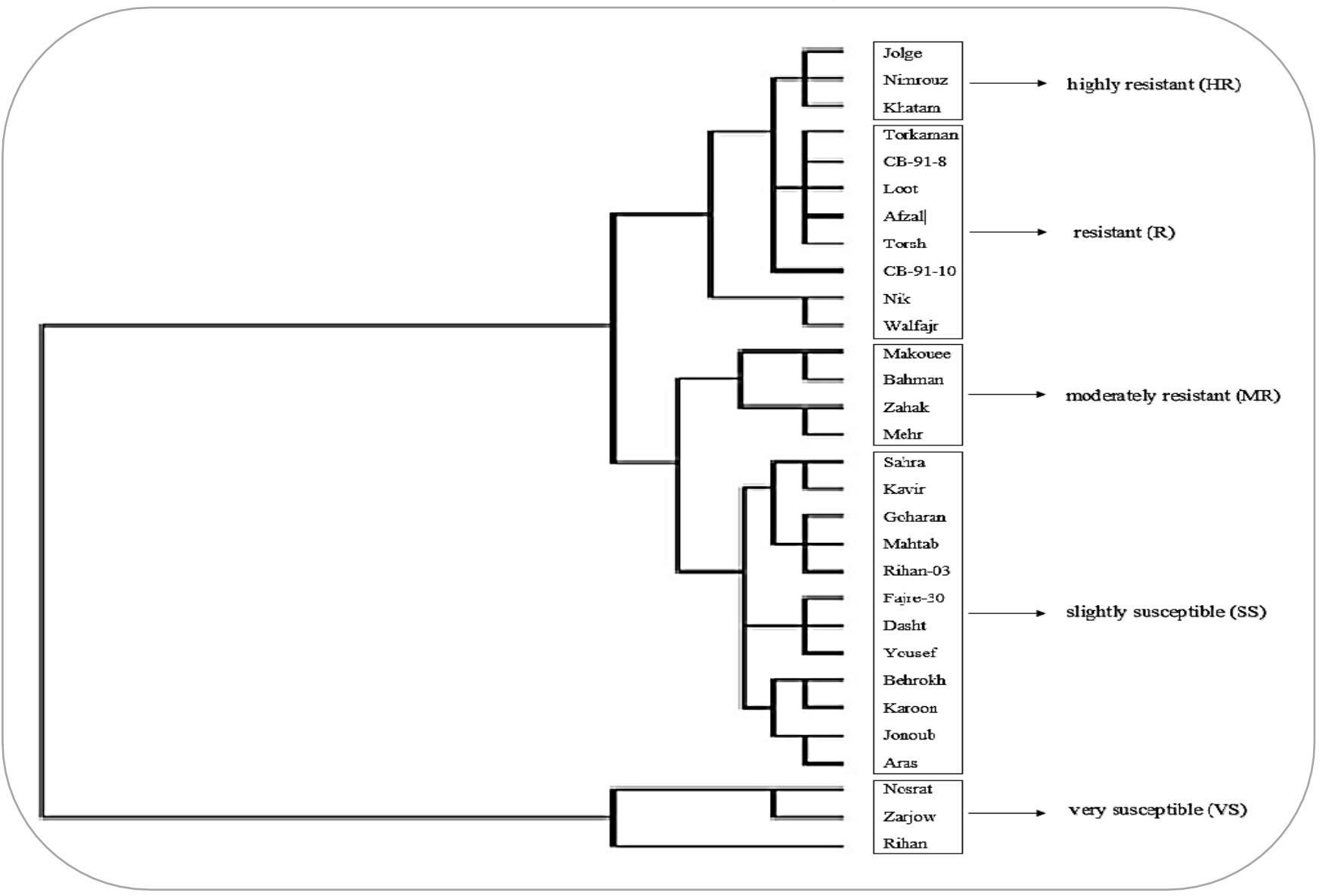

Figure 1. Tree diagram for comparing the Interaction of nematode induced and growth factors on barley cultivars and lines. 
Table 4. Influence of $M$. javanica on barley cultivars and lines under greenhouse conditions.

\begin{tabular}{|c|c|c|c|c|c|c|}
\hline \multirow[b]{2}{*}{ No. } & \multirow[t]{2}{*}{ Cultivar } & \multicolumn{2}{|c|}{ nematodes induced parameters } & \multicolumn{3}{|c|}{ growth parameters** } \\
\hline & & $\begin{array}{l}\text { Number of gall in per gram } \\
\text { root }\end{array}$ & $\mathrm{RF}^{*}$ & $\begin{array}{c}\text { Change plant fresh } \\
\text { weight (\%) }\end{array}$ & $\begin{array}{c}\text { Change plant dry } \\
\text { weight (\%) }\end{array}$ & $\begin{array}{c}\text { Change plant length } \\
(\%)\end{array}$ \\
\hline 1 & Makouee & $64.58 \pm 8.08^{\mathrm{bcde}}$ & $2.38 \pm 0.13^{\text {efghi }}$ & $20.61 \pm 1.63^{\text {hi }}$ & $49.27 \pm 0.71^{\mathrm{e}}$ & $2.97 \pm 0.99^{\mathrm{hi}}$ \\
\hline 2 & Bahman & $61.12 \pm 6.01^{\text {bcdef }}$ & $2.03 \pm 0.24^{\text {fghi }}$ & $26.17 \pm 1.03^{f}$ & $57.17 \pm 0.40^{\mathrm{d}}$ & $2.38 \pm 1.03^{\mathrm{hi}}$ \\
\hline 3 & Yousef & $69.87 \pm 12.61^{\mathrm{bc}}$ & $2.30 \pm 0.32^{\text {efghi }}$ & $41.46 \pm 0.72^{\mathrm{c}}$ & $23.93 \pm 1.72^{\mathrm{k}}$ & $6.56 \pm 2.84^{\text {cdefg }}$ \\
\hline 4 & Nosrart & $75.50 \pm 16.62^{b}$ & $2.69 \pm 0.97^{\text {efghi }}$ & $42.47 \pm 0.58^{c}$ & $65.20 \pm 0.33^{c}$ & $9.05 \pm 0.82^{c}$ \\
\hline 5 & Nik & $30.15 \pm 2.7 \mathrm{jklm}$ & $2.34 \pm 0.45^{\text {efghi }}$ & $37.51 \pm 0.63^{\mathrm{d}}$ & $17.82 \pm 1.03^{\mathrm{mn}}$ & $5.42 \pm 0.72^{\text {defghi }}$ \\
\hline 6 & Behrokh & $73.44 \pm 10.11^{b}$ & $3.15 \pm 0.59^{\text {defghi }}$ & $24.57 \pm 1.30^{g}$ & $37.15 \pm 0.78^{g}$ & $4.35 \pm 1.45^{\text {fghi }}$ \\
\hline 7 & Fajre-30 & $63.59 \pm 9.78^{\text {bcdef }}$ & $2.42 \pm 0.62^{\text {efghi }}$ & $33.07 \pm 0.66^{\mathrm{e}}$ & $10.11 \pm 0.87 \mathrm{pq}$ & $3.60 \pm 0.78^{\text {ghi }}$ \\
\hline 8 & Rihan & $103.48 \pm 7.47^{a}$ & $7.45 \pm 1.30^{\mathrm{a}}$ & $70.51 \pm 1.01^{\mathrm{a}}$ & $80.31 \pm 0.38^{a}$ & $28.31 \pm 0.79^{a}$ \\
\hline 9 & Nimrouz & $21.70 \pm 6.11^{\mathrm{lm}}$ & $1.75 \pm 0.41^{\mathrm{hi}}$ & $8.13 \pm 0.18^{\circ}$ & $7.91 \pm 1.47^{r}$ & $2.25 \pm 0.00^{\mathrm{i}}$ \\
\hline 10 & Sahra & $68.49 \pm 13.03^{\mathrm{bcd}}$ & $4.48 \pm 1.59 \mathrm{bcd}$ & $12.47 \pm 0.41^{\mathrm{m}}$ & $16.07 \pm 1.56^{\text {no }}$ & $4.97 \pm 3.76^{\text {defghi }}$ \\
\hline 11 & Jonoub & $62.23 \pm 10.55^{\text {bcdef }}$ & $3.65 \pm 0.82^{\text {cdef }}$ & $33.14 \pm 0.82^{\mathrm{e}}$ & $33.16 \pm 0.19^{\mathrm{h}}$ & $5.73 \pm 3.93^{\text {cdefgh }}$ \\
\hline 12 & Zahak & $55.31 \pm 11.42^{\text {cdefg }}$ & $5.08 \pm 1.90^{\mathrm{bc}}$ & $12.09 \pm 0.22^{\mathrm{m}}$ & $43.01 \pm 0.56^{\mathrm{f}}$ & $3.95 \pm 3.53^{\text {fghi }}$ \\
\hline 13 & Walfajr & $32.01 \pm 8.05^{\mathrm{jklm}}$ & $3.60 \pm 1.29^{\text {cdefg }}$ & $33.49 \pm 0.87 \mathrm{e}$ & $28.06 \pm 2.24 j$ & $7.96 \pm 2.28^{\text {cde }}$ \\
\hline 14 & Kavir & $67.16 \pm 10.08^{\mathrm{bcd}}$ & $3.80 \pm 1.90^{\text {bcde }}$ & $16.99 \pm 0.35^{\mathrm{k}}$ & $14.77 \pm 3.14^{\circ}$ & $2.92 \pm 0.72^{\mathrm{hi}}$ \\
\hline 15 & Zarjow & $76.09 \pm 6.44^{b}$ & $5.43 \pm 1.64^{b}$ & $56.02 \pm 0.93^{b}$ & $70.45 \pm 0.49^{b}$ & $17.26 \pm 2.73^{b}$ \\
\hline 16 & Aras & $49.69 \pm 14.92^{\text {efghi }}$ & $2.13 \pm 0.12^{\text {efghi }}$ & $36.44 \pm 0.90^{\mathrm{d}}$ & $30.96 \pm 1.44^{\mathrm{i}}$ & $4.58 \pm 0.72^{\text {efghi }}$ \\
\hline 17 & Loot & $32.13 \pm 4.39 \mathrm{jklm}$ & $2.51 \pm 1.62^{\text {efghi }}$ & $14.62 \pm 0.40^{1}$ & $16.36 \pm 0.39^{\text {no }}$ & $3.62 \pm 0.63^{\text {fghi }}$ \\
\hline 18 & Rihan-03 & $53.32 \pm 6.33^{\text {defgh }}$ & $1.92 \pm 0.94$ ghi & $19.99 \pm 0.34^{\mathrm{ij}}$ & $25.39 \pm 0.75^{\mathrm{k}}$ & $3.62 \pm 1.66^{\text {ghi }}$ \\
\hline 19 & Karoon & $65.44 \pm 13.97 \mathrm{bcd}$ & $3.40 \pm 1.29^{\text {cdefgh }}$ & $21.36 \pm 0.11^{\mathrm{h}}$ & $33.77 \pm 0.58^{\mathrm{h}}$ & $8.19 \pm 1.01^{\text {cd }}$ \\
\hline 20 & Dasht & $61.79 \pm 12.59$ bcdef & $2.12 \pm 0.62^{\text {efghi }}$ & $34.03 \pm 0.50^{\mathrm{e}}$ & $17.91 \pm 0.26^{\mathrm{mn}}$ & $8.16 \pm 4.08^{\mathrm{cd}}$ \\
\hline 21 & Torkaman & $38.02 \pm 11.60^{\mathrm{hijk}}$ & $2.83 \pm 1.64^{\text {defghi }}$ & $15.42 \pm 0.95^{1}$ & $16.31 \pm 1.36^{\mathrm{no}}$ & $5.73 \pm 0.90^{\text {cdefgh }}$ \\
\hline 22 & Torsh & $29.84 \pm 5.49 \mathrm{jklm}$ & $2.42 \pm 0.56^{\text {efghi }}$ & $10.73 \pm 0.56^{\mathrm{n}}$ & $21.18 \pm 2.04^{1}$ & $3.92 \pm 3.70^{\text {fghi }}$ \\
\hline 23 & Afzal & $35.25 \pm 4.61^{\mathrm{ijkl}}$ & $3.60 \pm 0.52^{\text {cdefg }}$ & $14.51 \pm 0.98^{1}$ & $11.40 \pm 0.70^{\mathrm{p}}$ & $3.29 \pm 0.81$ ghi \\
\hline 24 & Goharan & $49.82 \pm 1.02^{\text {efghi }}$ & $3.82 \pm 0.99 \mathrm{bcde}$ & $17.47 \pm 1.17^{\mathrm{k}}$ & $11.41 \pm 0.95^{p}$ & $4.17 \pm 0.66^{\text {ghhi }}$ \\
\hline 25 & Khatam & $25.51 \pm 4.13^{\mathrm{klm}}$ & $1.75 \pm 0.50^{\mathrm{hi}}$ & $8.49 \pm 0.17^{\circ}$ & $9.03 \pm 2.24 \mathrm{qr}$ & $3.29 \pm 2.15^{\text {ghi }}$ \\
\hline 26 & Mehr & $43.81 \pm 4.36^{\text {ghij }}$ & $2.22 \pm 1.23^{\text {efghi }}$ & $10.53 \pm 0.66^{\mathrm{n}}$ & $41.52 \pm 0.28^{\mathrm{f}}$ & $5.40 \pm 3.70^{\text {defghi }}$ \\
\hline 27 & CB-91-8 & $40.81 \pm 10.14^{\text {ghijk }}$ & $2.43 \pm 0.80^{\text {efghi }}$ & $17.14 \pm 0.61^{\mathrm{k}}$ & $19.30 \pm 1.14^{\mathrm{lm}}$ & $8.99 \pm 0.92^{c}$ \\
\hline 28 & CB-91-10 & $25.86 \pm 9.66^{\mathrm{klm}}$ & $3.37 \pm 1.46^{\text {cdefgh }}$ & $19.21 \pm 0.83^{j}$ & $27.84 \pm 1.78^{j}$ & $8.05 \pm 1.00^{\text {cd }}$ \\
\hline 29 & Jolge & $19.06 \pm 5.44^{\mathrm{m}}$ & $1.53 \pm 0.37^{\mathrm{i}}$ & $2.12 \pm 0.76^{p}$ & $4.76 \pm 1.76^{\mathrm{s}}$ & $2.14 \pm 0.74^{\mathrm{i}}$ \\
\hline 30 & Mahtab & $48.26 \pm 12.97^{\text {fghi }}$ & $2.38 \pm 0.70^{\text {efghi }}$ & $26.35 \pm 0.65^{\mathrm{f}}$ & $16.35 \pm 1.68^{\text {no }}$ & $6.99 \pm 0.93^{\text {cdef }}$ \\
\hline
\end{tabular}

*Final population/initial population.

**Growth parameters $=$ Changes in growth parameters relative to the control in term of percentage. 
Enzymes assay: After evaluating the resistance of the cultivars to the RKN, Jolge and Nimrouz cultivars as highly resistant and Zarjow and Rihan as susceptible to very susceptible cultivars were selected, then they were Table 5. Analysis variance of resistance enzyme activity.

\begin{tabular}{cccccc}
\hline \multirow{2}{*}{ Sources changes } & \multirow{2}{*}{ DF } & \multicolumn{4}{c}{ Mean squares } \\
\cline { 3 - 6 } & & Peroxidase & Polyphenol oxidase & Superoxide dismutase & Catalase \\
\hline Cultivar & 3 & $41123.40^{* *}$ & $0.0093^{* *}$ & $13.551^{* *}$ & $0.726^{* *}$ \\
Time & 3 & $9096.12^{* *}$ & $0.0035^{* *}$ & $3.838^{* *}$ & $0.662^{* *}$ \\
Cultivar $\times$ Time & 9 & $7193.28^{* *}$ & $0.0021^{* *}$ & $2.178^{* *}$ & $0.055^{* *}$ \\
\hline Error & 32 & 2.20 & 0.0000067 & 0.0092 & 0.00022 \\
\hline
\end{tabular}

**significant at $\mathrm{P}<0.01$.

Peroxidase activity: In the resistant cultivars (Jolge and Nimrouz), activity of PROX enzyme increased significantly after inoculation with nematode and peaked seven days after inoculation, but in susceptible cultivars, PROX activity decreased after inoculation, such that in Rihan cultivar, the enzyme activity increased on the third day after inoculation (82.56), and decreased on the fifth (49.95) and seventh days (41.35). In Zarjow, the amount of enzyme decreased in each stage $(107.24,89.95,83.21$ and 76.86 , respectively) (Figure 2).

Polyphenol oxidase activity: The highest amount of PPO enzyme was observed in Jolge 7 days after inoculation (0.205). PPO enzyme in resistant cultivars (Jolge and Nimrouz) decreased on the third day after inoculation and increased on the fifth and seventh days, while in the considered for enzyme assay. CAT, PROX, SOD, and PPO studied revealed that there is a significant difference among susceptible and resistant genotypes due to enzyme secretion in the roots (Table 5).

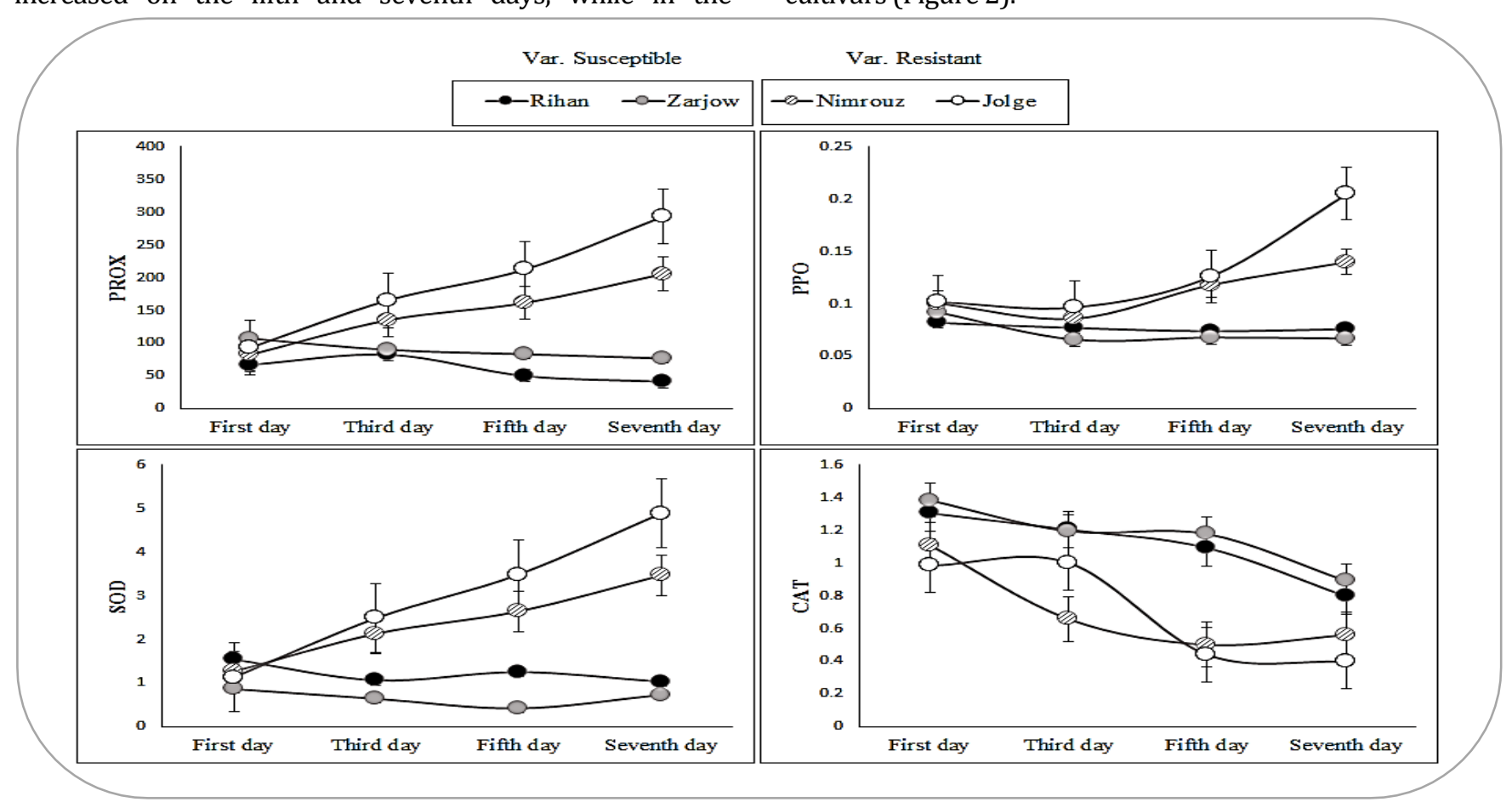

Figure 2. Enzyme activity (Catalase, Peroxidase, Polyphenol Oxidase and Superoxide Dismutase) in resistant and susceptible barley cultivars inoculated with $M$. javanica. 


\section{DISCUSSION}

All cultivars showed variability in their response to $M$. javanica infestation. None of the cultivars and lines was immune against nematode and the disease influenced on all cultivars and lines; however, different levels of resistance were observed among cultivars and lines. There were significant differences in infection levels between cultivars, such that Jolge and Nimrouz cultivars showed the highest resistance to M. javanica and Rihan and Zarjow showed the highest sensitivity to the nematode. The number of nematodes in the root system of Jolge decreased dramatically over the course of the experiment compared with Rihan, suggesting that the nematodes cannot reproduce in roots of the highly resistant cultivars or might have migrated out of the tissues. Jolge with characteristics such as winter growth, premature breeding, the height of $90 \mathrm{~cm}$, and resistance to lying and grain seed, powdery mildew (Blumeria graminis) and yellow rust (Puccinia striiformis) is considered an appropriate cultivar in most parts of Iran. Nimroz and Khatam cultivars were also highly resistant. Nimroz cultivar in previous studies showed resistance to drought, salinity, Septoria tritici, Ustilago hordei, Ustilago tritici. In addition, khatam cultivar showed tolerance to salinity and resistance to spike losses and lie down and semi-susceptible to yellow rust, powdery mildew and leaf spots. Results of this study revealed that this cultivar is also resistant to $M$. javanica. On the other hand, Rihan cultivar is semi-resistance to lying and grain seed, powdery mildew (B. graminis) and yellow rust $(P$. striiformis), and is appropriate for warm temperate regions, where conditions are provided for the growth of root-knot nematodes. Zarjow and Nosrat cultivars that arrange in susceptible groups witch Zarjow cultivar also susceptible to lie down and tolerance to chill and spike losses and resistance to salinity. Nosrat is semi-resistance to lie down, chill and drought. In addition, Nosrat is resistance to yellow rust and powdery mildew. According to the results of this study, if there was a root-knot nematode population in the cultivated field (with Rihan cultivar), the amount of damage to the product will be high. Ibrahim et al. (1988) compared the resistance of five barley cultivars against $M$. javanica and reported that all tested cultivars have relative susceptibility to this nematode and these findings are consistent with the results of this study. Johnson and Motsinger (1989) by examining the damage of $M$. javanica, $M$. incognita, $M$. arenaria on seven cultivars of wheat, five oats, and four barley cultivars, reported susceptibility in all tested plant species except two cultivars of Brooks and Florida 051 that were resistant to M. arenaria and M. javanica species. In comparing resistance study of 14 barley cultivars, seven wheat and four oat to RKN (M. javanica) in the initial infection, 1000 eggs and larvae, one of the cultivars of wheat and two barley cultivars were introduced as susceptible to nematode (Karajeh et al., 2011). Before this, no study has been conducted on the level of oxidative enzymes secretion against RKN nematodes in barley cultivars in Iran. Overall, plant diseases are causing change in resistance enzymes activity and there are several reports based on the relative resistance and increase in antioxidant enzyme activity (Ngadze et al., 2012; Arun et al., 2010; Moghbeli et al., 2017). In this study, the increase of SOD, PROX, PPO and suppression of CAT activity in Jolge and Nimrouz was higher than that in Rihan and Zarjow. The increased trend of PROX activity was a response of resistance that barley showed to $M$. javanica. PROX plays a special role in the construction of cell wall lignin that might increase the structural rigidity of plant tissues and halt nematode penetration (Quiroga et al., 2000; Anjum et al., 2012). Increase in the amount of resistance enzymes has been confirmed against different plant pathogens in several studies (Potpour et al., 2000; Kuvalekar et al., 2011; Anjum et al., 2012). These changes are represented in infected tissues especially in resistant cultivars (Dixit et al., 2017) that was quite consistent with the findings of this study. In addition, evaluation in the frequency of resistance enzymes to fungal disease (Fusarium oxysporum F. SP. Radices-cucumerinum) overlapped with our results (Moghbeli et al., 2017). In our study, after nematode inoculation, PROX activity increased in resistant cultivars according to Nayak and Pandey (2016) and Dixit et al. (2017) studies. Aemmr et al. (2014) stated that SOD activity decreased when PROX activity increased in resistant cultivars, while in the present study, SOD activity increased in resistant cultivars and had a direct correlation with PROX activity. These results are in line with Guida et al. (1992) who reported that increase in SOD and PROX activity seems to be the result of an adaptive response, which provides the plant with protection against biotic and abiotic stress. CAT activity decreased in resistant and susceptible cultivars, but this reduction was more pronounced in resistant cultivars than susceptible cultivars. The findings of the current study were in agreement with those reported by Wynn et al., (2013). Chen et al. (1993) reported that 
Salicylic acid caused as inhibition in CAT activity in many plants, and improved plant systemic acquired resistance (SAR). CAT inhibition was reported to enhance the cellular level of $\mathrm{H}_{2} \mathrm{O}_{2}$, which was recognized in $\mathrm{HR}$, as a trigger for hypersensitive cell death as well as a strong antimicrobial molecule (Arun et al., 2010). Similar to PROX and SOD, PPO activity increased after nematode inoculation in resistant cultivars and decreased or did not change in susceptible cultivars. Rani et al. (2008) and Wynn et al., (2013) also obtained similar results with our study. Our results indicated that measuring oxidative enzymes can be used as a biochemical marker to predict the level of resistance of barley genotypes to M. javanica. According to other reports and the results of our study, it cannot be indicated that barley is fully resistant to RKN, and by introducing resistant cultivars of this plant, can help to reduce nematode damage.

\section{CONCLUSIONS}

Today's, one of the most important and controversial issues is to introduce resistant or tolerant varieties to disease and tensions because, resistant varieties can help in growth production in agriculture without environmental damages. According to other reports and the results of our study, it cannot be indicated that barley is immune to RKN, and by introducing resistant cultivars of this plant, can help to reduce nematode damage. As In this study results showed that Jolge and Nimrooz varieties are most resistance to the disease and suitable for future genomical and biotechnical investigations. In addition, results indicated that measuring oxidative enzymes can be used as a biochemical marker to predict the level of resistance of barley genotypes to M. javanica.

\section{ACKNOWLEDGEMENTS}

The authors wish to thank to Ms. Dolatabadi, Kh. (Ph.D. student of horticulture from Ferdowsi University of Mashhad-Razavi Khorasan province-Iran) for their help in analyzing enzymatic data.

\section{REFERENCES}

Abad, P., B. Favery, M.-N. Rosso and P. Castagnone-Sereno. 2003. Root-knot nematode parasitism and host response: molecular basis of a sophisticated interaction. Molecular Plant Pathology, 4: 217-224.

Aboulipour, M., M. Olia, A. Fadaee and M. Kadivar. 2011. Reaction of some cucumber cultivars to root-knot nematode, Meloidogyne javanica. Iranian Journal of Plant Pathology, 47: 279-291.

Abrahim, N. N., M. S. Kanthimathi and A. Abdul-Aziz. 2012. Piper betle shows antioxidant activities, inhibits
MCF-7 cell proliferation and increases activities of catalase and superoxide dismutase. BMC Complementary and Alternative Medicine, 12.

Aebi, H. 1984. Catalase in vitro. Methods in Enzymology. Elsevier, pp. 121-126.

Aemmr, A., A. Farahat, A. Al-Sayed and N. Mahfoud. 2014. Antioxidant enzymes as well as oxidant activities involved in defense mechanisms against the rootknot, reniform and citrus nematodes in their host plants. International Journal of Biotechnology and Food Science, 2: 102-111.

Anjum, T., S. Fatima and S. Amjad. 2012. Physiological changes in wheat during development of loose smut. Tropical Plant Pathology, 37: 102-107.

Beauchamp, C. and I. Fridovich. 1971. Superoxide dismutase: Improved assays and an assay applicable to acrylamide gels. Analytical Biochemistry, 44: 276-287.

Bradford, M. 1976. A rapid and sensitive method for the quantitation of microgram quantities of protein utilizing the principle of protein-dye binding. Analytical Biochemistry, 72: 248-254.

Chen, Z., H. Silva and D. Klessig. 1993. Active oxygen species in the induction of plant systemic acquired resistance by salicylic acid. Science, 262: 18831886.

Czembor, J. H., H. J. Czembor, G. Attene and R. Papa. 2007. Leaf rust resistance in selections from barley landraces collected in Sardinia. Plant Breeding and Seed Science, 56.

De Grisse, A. T. 1969. Redescription and modification of some techniques used in the study of nematodes phytoparasitaires. Mededelingen Rijksfacultiet Landbouw Wetenschappe Gent, 34: 351-369.

Dhandaydham, M., L. Charles, H. Zhu, J. L. Starr, T. Huguet, D. R. Cook, J.-M. Prosperi and C. Opperman. 2008. Characterization of root-knot nematode resistance in Medicago truncatula. Journal of nematology, 40: 46.

Dixit, A., G. Das, P. Dixit, A. Singh, N. Kumbhakar, M. Sankar and R. Sharma. 2017. An assessment of benzimidazole resistance against caprine nematodes in Central India. Tropical animal health and production, 49: 1471-1478.

EL-Mesalamy, A. F. M. 2013. Resistance of some plant cultivars wheat, barley and broad bean to root-knot nematode, Meloidogyne Javanica. EJAN, 12: 130138. 
Esterbauer, H., E. Schwarzl and M. Hayn. 1977. A rapid assay for catechol oxidase and laccase using 2nitro-5-thiobenzoic acid. Analytical Biochemistry, 77: 486-494.

Ghaderi, R., L. Kashi and A. Karegar. 2014. $<$ strong>Contribution to the study of the genus $<$ em>Paratylenchus</em> Micoletzky, 1922 sensu lato (Nematoda: Tylenchulidae)</strong $>$. Zootaxa, 3841: 151.

Guida, G., G. Zacheo and T. Bleve-Zacheo. 1992. Activation of detoxifying enzymes in tomato roots following paraquat treatment and nematode infection. Nematologia Mediterranea, 20: 203-209.

Harris, K. F. and K. Maramorosch. 2013. Pathogens, vectors, and plant diseases: approaches to control. Elsevier.

Hartman, K. and J. Sasser. 1985. Identification of Meloidogyne species on the basis of differential host test and perineal-pattern morphology.

Holterman, M., K. Rybarczyk, S. Van Den Elsen, H. Van Megen, P. Mooyman, R. P. Santiago, T. O. M. Bongers, J. Bakker and J. Helder. 2008. A ribosomal DNA-based framework for the detection and quantification of stress-sensitive nematode families in terrestrial habitats. Molecular Ecology Resources, 8: 23-34.

Hussain, M. A., T. Mukhtar and M. Z. Kayani. 2016. Reproduction of Meloidogyne incognita on resistant and susceptible okra cultivars. Pakistan Journal of Agricultural Sciences, 53: 371-375.

Hussey, R. 1973. A comparison of methods of collecting inocula of Meloidogyne spp., including a new technique. Plant Dis. Rep., 57: 1025-1028.

Ibrahim, I., M. Rezk and A. Ibrahim. 1988. Resistance of barley and wheat cultivars to root-knot nematodes, Meloidogyne spp. Pakistan Journal Nematology, 6: 39-43.

Jenkins, W. 1964. A rapid centrifugal-flotation technique for separating nematodes from soil. Plant disease reporter, 48.

Jepson, S. B. 1987. Identification of root-knot nematodes (Meloidogyne species).

Johnson, A. and R. Motsinger. 1989. Suitability of small grains as hosts of Meloidogyne species. Journal of Nematology, 21: 650.

Kaloshian, I., P. Roberts and I. Thomason. 1989. Resistance to Meloidogyne spp. in allohexaploid wheat derived from Triticum turgidum and Aegilops squarrosa. Journal of nematology, 21: 42.

Kar, M. and D. Mishra. 1976. Catalase, Peroxidase, and Polyphenoloxidase Activities during Rice Leaf Senescence. Plant Physiology, 57: 315-319.

Karajeh, M., A. Abdel-Ghani and N. Al-Majali. 2011. Response of wheat, barley and oat cultivars and accessions to Meloidogyne javanica. Nematologia Mediterranea, 39.

Karuri, H. W., D. Olago, R. Neilson, E. Mararo and J. Villinger. 2017. A survey of root knot nematodes and resistance to Meloidogyne incognita in sweet potato varieties from Kenyan fields. Crop Protection, 92: 114-121.

Kayani, M. Z. and T. Mukhtar. 2018. Reproductivity of Meloidogyne incognita on Fifteen Cucumber Cultivars. Pakistan Journal of Zoology, 50.

Kayani, M. Z., T. Mukhtar and M. A. Hussain. 2018. Interaction between Nematode Inoculum Density and Plant Age on Growth and Yield of Cucumber and Reproduction of Meloidogyne incognita. Pakistan Journal of Zoology, 50.

Kumar, A., P. Mali and V. Manga. 2010. Changes of some phenolic compounds and enzyme activities on infected pearl millet caused by Sclerospora graminicola. International Journal of plant physiology and biochemistry, 2: 6-10.

Kuvalekar, A., A. Redkar, K. Gandhe and A. Harsulkar. 2011. Peroxidase and polyphenol oxidase activities in compatible host-pathogen interaction in Jasminum officinale and Uromyces hobsoni: Insights into susceptibility of host. New Zealand Journal of Botany, 49: 351-359.

Mahdy, M. E. and M. Sally A. 2011. Physiological response of strawberry grown in root- knot nematode infested soil under different safety control applications. Arab Universities Journal of Agricultural Sciences, 19: 217-231.

Mehta, A., A. C. M. Brasileiro, D. S. L. Souza, E. Romano, M. A. Campos, M. F. Grossi-de-Sá, M. S. Silva, O. L. Franco, R. R. Fragoso, R. Bevitori and T. L. Rocha. 2008. Plant-pathogen interactions: what is proteomics telling us? FEBS Journal, 275: 37313746.

Mittler, R. 2002. Oxidative stress, antioxidants and stress tolerance. Trends in Plant Science, 7: 405-410.

Moens, Maurice, Roland N. Perry, and James L. Starr. 2009. "Meloidogyne species-a diverse group of novel and important plant parasites." Root-knot 
nematodes $1: 483$.

Moghbeli, E., S. H. Nemati, H. Aroiee and J.-A. Olfati. 2017. Evaluation of resistance, enzymatic response, and phenolic compounds in roots of F1 cucumber hybrids to Fusarium oxysporum f. sp. radiciscucumerinum. Journal of Horticultural Research, 25: 117-124.

Mohammadi, M. and H. Kazemi. 2002. Changes in peroxidase and polyphenol oxidase activities in susceptible and resistant wheat heads inoculated with Fusarium graminearum and induced resistance. Plant Science, 162: 491-498.

Mukhtar, T. 2018. Management of Root-Knot Nematode, Meloidogyne incognita, in Tomato with Two Trichoderma Species. Pakistan Journal of Zoology, 50.

Mukhtar, T., M. A. Hussain, M. Z. Kayani and M. N. Aslam. 2014. Evaluation of resistance to root-knot nematode (Meloidogyne incognita) in okra cultivars. Crop Protection, 56: 25-30.

Nayak, D. K. and R. K. Pandey. 2016. Physiological and Biochemical changes of susceptible and resistant brinjal cultivars induced by root-knot nematode, Meloidogyne incognita. Journal of Global Biosciences, 5: 4358-4368.

Ngadze, E., D. Icishahayo, T. A. Coutinho and J. E. van der Waals. 2012. Role of polyphenol oxidase, peroxidase, phenylalanine ammonia lyase, chlorogenic acid, and total soluble phenols in resistance of potatoes to soft rot. Plant Disease, 96: 186-192.

Oliveira, J. T. A., N. C. Andrade, A. S. Martins-Miranda, A. A. Soares, D. M. F. Gondim, J. H. Araújo-Filho, F. R. Freire-Filho and I. M. Vasconcelos. 2012. Differential expression of antioxidant enzymes and PR-proteins in compatible and incompatible interactions of cowpea (Vigna unguiculata) and the root-knot nematode Meloidogyne incognita. Plant Physiology and Biochemistry, 51: 145-152.

Opperman, C. H. 1988. Reproduction of Three Root-Knot Nematodes on Winter Small Grain Crops. Plant Disease, 72: 869.

Potpour, M., M. Mohammadi, M. Torabi and A. SharifiTehrani. 2000. Peroxidase specific activity pattern in resistant and susceptible barley seedlings inoculated with Erysiphe graminis f. sp. hordei, the causal agent of powdery mildew disease. Iranian
Journal of Agricultural Sciences, 31: 415-426.

Quiroga, M., C. Guerrero, M. A. Botella, A. Barceló, I. Amaya, M. a. I. Medina, F. J. Alonso, S. M. de Forchetti, H. Tigier and V. Valpuesta. 2000. A tomato peroxidase involved in the synthesis of lignin and suberin. Plant Physiology, 122: 11191128.

Rani, C. I., D. Veeraragavathatham and S. Sanjutha. 2008. Analysis on biochemical basis of root-knot nematode (Meloidogyne incognita) resistance in tomato (Lycopersicon esculentum Mill.) Res. J Agric Biol Sci, 4: 866-870.

Sairam, R. and A. Tyagi. 2004. Physiology and molecular biology of salinity stress tolerance in plants. Current science: 407-421.

Sankar, G. (2017). U.S. Patent No. 9,608,454. Washington, DC: U.S. Patent and Trademark Office.

Singh, S. K. and U. R. Khurma. 2007. Susceptibility of six tomato cultivars to the root-knot nematode, Meloidogyne incognita. The South Pacific Journal of Natural and Applied Sciences, 25: 73.

Suzuki, T., T. Kobayashi, K. Adachi, H. Mochida, H. Iwahori, Y. Tateishi and K. Uesugi. 2012. Effect of Introducing Nematode-Resistant Sweet Potato Cultivars on Crop Productivity and Nematode Density in Sweet Potato-Radish Double-Cropping Systems. Plant Production Science, 15: 48-56.

Taylor, A. and J. Sasser. 1978. Biology, identification and control of root-knot nematodes. North Carolina State University Graphics, 111.

Tutt, A., Robson, M., Garber, J. E., Domchek, S. M., Audeh, M. W., Weitzel, J. N., \& Wardley, A. (2010). Oral poly (ADP-ribose) polymerase inhibitor olaparib in patients with BRCA1 or BRCA2 mutations and advanced breast cancer: a proof-of-concept trial. The Lancet, 376(9737), 235-244.

Whitehead, A. G. and J. R. Hemming. 1965. A comparison of some quantitative methods of extracting small vermiform nematodes from soil. Annals of Applied Biology, 55: 25-38.

Wynn, T. A., Chawla, A., \& Pollard, J. W. (2013). Macrophage biology in development, homeostasis and disease. Nature, 496(7446), 445.

Yu, Q., \& Rengel, Z. (1999). Micronutrient deficiency influences plant growth and activities of superoxide dismutases in narrow-leafed lupins. Annals of Botany, 83(2), 175-182. 